Dementia and Geriatric Cognitive Disorders
Journal Home

Editorial Board

Guidelines

$\underline{\text { Issues }}$
Advertising

Subscriptions

Free Alert

Online Sample

Vol. 20, No. 1, 2005 June 2005

\title{
原著論文
}

1 台湾痴呆患者における Heat Shock Protein 70 (HSP70)と

Tumor Necrosis Factor Alpha(TNF $\alpha$ )

Fung, H.C. ; Chen, C.M. ; Wu, Y.R. ; Hsu, W.C. ; Ro, L.S. ; Lin, J.C. ;

Chang, K.H. ; Wang, H.K. ; Lin, S.J.; Chan, H. ; Lin, Y.Y. ; Wei, S.L. ;

Hsu, Y. ; Hwang, J.C. ; Tung, L.C. ; Lee-Chen, G.-J.

Dement Geriatr Cogn Disord 2005;20:1-7 (DOI:10.1159/000085067)

Free Abstract Article (References) Article (PDF $213 \mathrm{~KB}$ )

\section{8 予備認知機能:}

教育歴O 19年の 132 人アルツハイマー病患者における SPECT 研究

Liao, Y.-C. ; Liu, R.-S. ; Teng, E.L.; Lee, Y.-C. ; Wang, P.-N. ; Lin, K.-N. ;

Chung, C.-P.; Liu, H.-C.

Dement Geriatr Cogn Disord 2005;20:8-14 (DOI:10.1159/000085068)

Free Abstract Article (References) Article (PDF $283 \mathrm{~KB}$ )

15 アルツハイマー病患者における塩酸ドネペジルに対する反応性に 血管障害とそれに関係するリスクファクターは影響するか？

Fukui, T.; Taguchi, S.

Dement Geriatr Cogn Disord 2005;20:15-24 (DOI:10.1159/000085069)

Free Abstract Article (References) Article (PDF $153 \mathrm{~KB}$ )

25 脳 SPECT を用いたアルツハイマー病患者とレビィ小体病の鑑別

Shimizu, S. ; Hanyu, H. ; Kanetaka, H. ; Iwamoto, T. ; Koizumi, K. ; Abe, K. Dement Geriatr Cogn Disord 2005;20:25-30 (DOI:10.1159/000085070)

Free Abstract Article (References) Article (PDF $183 \mathrm{~KB}$ )

31 韓国人アルツハイマー病患者における 5-HTTLPR ポリモルフィズムと疾患の相関

Ha, T.M. ; Cho, D.M. ; Park, S.W. ; Joo, M.J. ; Lee, B.J. ; Kong, B.G. ;

Kim, J.M. ; Yoon, J.S.; Kim, Y.H.

Dement Geriatr Cogn Disord 2005;20:31-34 (DOI:10.1159/000085071)

Free Abstract Article (References) Article (PDF $96 \mathrm{~KB}$ ) 
35 血清中のホモシスチン濃度と高齢患者における血管病症状との関連

Nilsson, K. ; Gustafson, L. ; Hultberg, B.

Dement Geriatr Cogn Disord 2005;20:35-41 (DOI:10.1159/000085072)

Free Abstract Article (References) Article (PDF $117 \mathrm{~KB}$ )

42 Dementia Rating Scale-2 の試験-再試験間信頼性: Alternate Form

Schmidt, K.S. ; Mattis, P.J. ; Adams, J. ; Nestor, P.

Dement Geriatr Cogn Disord 2005;20:42-44 (DOI:10.1159/000085073)

Free Abstract Article (References) Article (PDF $76 \mathrm{~KB}$ )

45 抗酸化性ビタミンの補充と認知機能低下と痴呆に対するリスク

Maxwell, C.J. ; Hicks, M.S. ; Hogan, D.B. ; Basran, J. ;

Ebly, E.M.

Dement Geriatr Cogn Disord 2005;20:45-51 (DOI:10.1159/000085074)

Free Abstract Article (References) Article (PDF $109 \mathrm{~KB}$ )

52 中国人におけるアンギオテンシン変換酵素遺伝子多型と

アルツハイマー病との相関

Zhang, J.-W. ; Li, X.-Q. ; Zhang, Z.-X. ; Chen, D. ; Zhao, H.-L. ;

Wu, Y.-N. ; Qu, Q.-M. ;

Dement Geriatr Cogn Disord 2005;20:52-56 (DOI:10.1159/000085075)

Free Abstract Article (References) Article (PDF $112 \mathrm{~KB}$ )

Dementia

and Geriatric

Cognitive Disorders
Journal Home

Editorial Board

Guidelines

Issues
Advertising

Subscriptions

Free Alert

Online Sample

Copyright @ 2005 S. Karger AG, Basel 